\title{
Civil Service Models in Latin America
}

\author{
Bastián González-Bustamante ${ }^{1}$ \\ ${ }^{1}$ Instructor Professor, Department of Public Administration and Policy, Faculty of Economics and \\ Management, Universidad de Santiago de Chile, $\bowtie$ bastian.gonzalez.b@usach.cl, ORCID iD \\ http://orcid.org/0000-0003-1510-6820
}

\section{Note}

Preliminary version of chapter published in Global Encyclopedia of Public Administration, Public Policy, and Governance, A. Farazmand, ed., Springer, New York, 2018.

\section{DEFINITION}

Although there are several definitions for civil service models, one simple operational definition describes them as systems of public employment management and human resources management (Echeberría 2006). There are also more complex conceptualisations which define them as a set of legal rules and instruments which enable the State to assure a staff of civil servants who are apt for the efficient functioning of its distinct levels of administration (Oszlak 2001). The Ibero-American Charter for the Public Service, signed by the Latin American governments in 2003, indicates that the civil service models must aim towards a professional administration and merit-based recruitment processes. Additionally, the Organization for Economic Co-operation and Development (OECD) highlights that the recruitment of civil servants must guarantee equal opportunities (OECD 2008). Despite the wide use of this concept, its dissemination and acceptance have been lesser in Latin America and it is frequently replaced by the public function concept.

\section{INTRODUCTION}

One of the main characteristics of Weber's bureaucratic model was selection by neutral competence, that is, the civil servants be selected according to norms of performance and merit, and 
not for personal characteristics or beliefs (Peters 1995). The fundamental value in the search for neutral competence was the capacity to professionalise government management and public administration (Kaufman 1956). This professionalisation is relevant since it determines the capacity of public organisms, which affects the processes of formulation and implementation of public policies (Farazmand 1997).

Nevertheless, merit in the public sector is something complex to define, since personal characteristics or beliefs can positively influence government efficiency (Peters 1995). In fact, political appointees and spoil systems have advantages like the development of a committed bureaucracy. The controversy between merit-based recruitment and the political appointee is associated with the politics-administration dichotomy. This concept refers to the traditional idea that proposes separating the political sphere from the administrative within government (Wilson 1887). According to Peters (1995), this controversy is a question of degree, since all political systems make political appointments at a certain level and additionally have posts which are filled in a routine manner according to some type of merit system.

Even though currently, the politics-administration dichotomy tends to be considered a simplistic vision of public administration and bureaucracy (Frederickson et al. 2012), the tension between merit and partisanship in the appointment of civil servants remains as an academic debate and the discussion continues in different spheres (Olavarría-Gambi and Dockendorff 2016). The defenders of professionalisation conceive of the systems of selection and recruitment based on merit as a public good which permits the prevention of the political use of the administration. On the other hand, the counter-argument affirms that professionalisation can produce an autonomy that is damaging for democratic representativeness (Farazmand 1989; 1997; Olavarría-Gambi and Dockendorff 2016; Rockman 1996).

This chapter examines the concept of public service models with special emphasis on the Latin American reality. The following section deals with the subject from an historical perspective, its ties to the patronage systems, and the main milestones which have shaped the evolution of the civil services. Subsequently, the next section deals with the chief characteristics and changes in the civil 
services and presents an evaluation of the models in Latin America. Finally, the last section sets out some brief conclusions and summarises the main ideas of this entry.

\section{THE CIVIL SERVICE MODELS FROM AN HISTORICAL PERSPECTIVE}

According to Raadschelders and Rutgers (1996), it is possible to identify different stages in the historical development of the civil service models. First, during feudalism and the late Middle Ages, it is possible to identify civil servants subordinate to a specific ruler. Later, during the seventeenth and eighteenth centuries, civil servants are employed by the State, a situation which permitted the differentiation of the public sphere from the private. After that, during the nineteenth century, civil servants were considered as agents that were not only in the service of the State, but at this point, the administration tended to be independent of political power and the politics-administration dichotomy emerges. Lastly, in the twentieth century, professional civil service models consolidate with the aim of providing adequate public goods and services.

From another perspective, following Grindle (2012), the emergence of the civil service models can be associated with patronage systems and clientelism which date back to the eighteenth century. These systems emerged from an institutional architecture where academic credentials were of great relevance for obtaining positions of privilege in the State. This benefited the political and social elites of the period. In Great Britain and France, for example, clientelism worked as a mechanism to guarantee the access of the elite to public employment and to ensure their well-being. In Japan and Prussia, on the other hand, clientelism and civil service models were an instrument for the construction and consolidation of authoritarian States.

In Latin America, patronage systems and clientelism dating back to the nineteenth and twentieth centuries are also to be found (Grindle 2012). During the nineteenth century, the independence movements eradicated a sizeable part of the Spanish and Portuguese colonial heritage. However, the patronage systems and clientelism remained intact as elements peculiar to Latin American politics. Due to the aforementioned, public employment did not adjust to meritocratic logic; rather, it was reserved for certain social groups and it was used as an element to negotiate political loyalties (Grindle 2012; Nef 2003). The consolidation of the Latin American civil service models has 
historically been tied to critical junctures, i.e. corruption scandals, political or economic crises, among others. Notwithstanding this, the different reforms promoted have not managed to eliminate the latent patronage systems and clientelism (Grindle 2012).

During the twentieth century, the civil service models gradually consolidated, especially in the United States, Europe, and Japan. This involved putting to one side the spoil systems and patronage. Also public services began to align their services with the user-satisfaction. This tendency became consolidated with the emergence of New Public Management (Grindle 2012). This concept is associated with a set of administrative doctrines and neo-managerial reforms which dominated the agenda of several OECD countries from the late 1970s. The central premise to these doctrines can be summed up as directing State organisations as if they were private enterprises and that public directors must have high levels of discretion in order to make efficient use of available resources (Christensen and Lægreid 2011; Hood 1991; Llano 2015).

This was complemented by the World Bank's first-generation reforms, which promoted the deregulation of markets, privatisation of public companies, outsourcing of services, reduction of public spending, as well as an important reduction in the size of civil services (Oszlak 2001). These neoconservative reforms are associated with the rise in neoliberal politics in Latin America from the time of the Washington Consensus. The package of neoconservative and neomanagerial reforms was considered a fundamental piece for the progress of democracies in development (Llano 2015; Pollitt and Bouckaert 2002). This produced what Olsen (2006) called modernisation by imitation.

Subsequently, the second-generation reforms were implemented with the extended Washington Consensus. These reforms were less neoconservative, e.g. prudent openness to capital, the fight against corruption, focused poverty-reduction policies, and the creation of social security networks. This boosted a revindication by the public sector through an institutional strengthening to generate regulation capacities and the creation of anti-corruption organisms (Santiso 2001).

In this context, the need to reduce political appointments became relevant. Moreover, the existence of a group of senior civil servants separated from the political sphere and from the classical bureaucracy became a fundamental value for the reforms of the Latin American civil service models 
(Ramos and Scrollini 2013). This, added to the growing need to rely on professional models of public services, was reflected in the Santa Cruz Consensus of June 2003 within the framework of the Fifth Ibero-American Conference of Ministers of Public Administration and State Reform. In this instance, the Latin American governments signed the Ibero-American Charter for Public Service, which defines the fundamentals for a professional public service and assigns orienting principles for its creation.

\section{CHARACTERISTICS AND CHANGES OF CIVIL SERVICE MODELS}

The Ibero-American Charter for the Public Service indicates that there is a positive correlation between the professionalisation of a civil service and the levels of confidence of citizens in the public administration, government efficiency, levels of transparency, and the capacity to generate economic growth. A professionalised civil service model has a positive impact on economic and democratic development and on overcoming poverty (Evans and Rauch 1999; Henderson et al. 2007; Lafuente et al. 2013). The civil service is relevant for State capacity since it generates incentives and restrictions for the action of public organisms in a transversal way (Barzelay 2001). Moreover, it represents an important State investment, since on average salary costs in central administration of the Latin American countries represents $5.6 \%$ of the GDP and $27 \%$ of total public spending (Cortázar et al. 2014a).

A civil service model can be classified according to its degrees of openness and the tension between its level of politicisation and professionalisation (Ballart and Ramió 2000; GonzálezBustamante et al. 2016; Ramió and Salvador 2005). The degrees of openness determine whether the model is open or closed. An open model is founded on the selection of civil servants based on their technical specialisation. In contrast, a closed model favours life-long tenure, which implies that civil servants must be versatile and adapt to the different needs of the organisation throughout their career. It is possible to find mixed models which mix specialisation and versatility.

The relation between politicisation and professionalisation, on the other hand, takes account of the tension between the prioritisation of professional merits and political confidence. All the civil service models possess political appointees and career officials, appointed in a routine manner 
according to some system of merit. What do vary are the limits; that is, until what hierarchical level are appointments based on merit, and where do political appointments begin? (Peters 1995). Usually, political appointees are designated for shorter periods than career officials (Lewis 2008; Resh 2015). The traditional civil service models have a limited capacity to produce senior civil servants, which is why professionalisation fostered a differentiation between the managerial function and the ordinary civil service. This is how senior civil services emerged. In some countries, the managerial function is differentiated, e.g. Belgium, Canada, Chile, the United States, Holland, Italy, New Zealand, the United Kingdom, Sweden. In other cases, the civil servant career and the managerial level are not separated, e.g. Germany, Austria, Colombia, Spain, France, Japan, Mexico (Longo 2003; Martínez Puón 2012).

In the models with high levels of politicisation, there is a sensation of violation of the acceptable limits of the balance between political nominations and merit-based appointments (Peters and Pierre 2004). They can even become similar to the American spoil system of the nineteenth century (Ramió and Salvador 2005). Nevertheless, although politicisation does have a generally negative connotation, it also has potentially positive aspects since it can generate a more committed bureaucracy which invigorates the public service, something which is not possible with a neutral bureaucracy (Peters and Pierre 2004). The politicised models can be open-circuit or closed (Quermonne 1995). The open-circuit model implies a selection of civil servants based on political confidence subsidised by professional criteria. The closed-circuit, in contrast, implies direct nominations that give preference to political confidence with the presence of some professional merits.

The reforms of the Latin American civil service models have been conditioned by the process of modernisation of public management and the fight against corruption (Barzelay 2003; Lafuente et al. 2013). There are several cases in which there is no specific model, whereas in others there are highly professionalised services, particularly in the diplomatic area (Ramió and Salvador 2005). On the other hand, countries such as Bolivia and Mexico have tried to implement civil services in some areas since the 1990s. There are also cases such as Chile, which historically had a model of 
civil service which was dismantled by the military dictatorship and in the past decade has fostered changes and revisions of its institutionalism (González-Bustamante et al. 2016).

Over the past decades, there has been a noticeable tension stemming from the institutional strength or weakness of the different civil service models in Latin America. On the one hand, there are countries whose institutional frameworks permit the prediction of a positive evolution of their civil service models. However, other cases present problems with respect to the political capacity to reach agreements and drive reforms (Echeberría 2006). In this context, diverse civil service models have been created or have been completely reformed since 1990, e.g. Argentina, Bolivia, Colombia, Ecuador, Mexico, Nicaragua, Panama, Paraguay, Peru, the Dominican Republic, and Venezuela. Others have undergone significant reforms over the past decade, e.g. Brazil, Chile, and Uruguay.

\section{EVALUATION OF THE CIVIL SERVICE MODELS IN LATIN AMERICA}

Although the degrees of openness and the tension between politicisation and professionalisation are relevant, they are not the only elements for classifying a civil service model. According to Longo (2001), it is possible to distinguish at least four key elements: (i) systems of access to employment; (ii) organisation of the career; (iii) the recognition of rights of civil servants; and (iv) administration of the system. For example, with respect to the systems of access particularly, at least three classical models can be distinguished: (i) the French model, which emphasises tenders and civil servant schools; (ii) the German model, focused on the process of extended learning in different stages among which there is a preparatory stage and different exams which enable the exercise of public functions; and (iii) the British model, with an emphasis on the professionalisation and independence of the organisms in charge of the system.

An effective way of evaluating the changes in the Latin American civil service models is to use the methodology of the Inter-American Development Bank (IDB), which is based on the IberoAmerican Charter for Public Service to measure critical points and evaluate civil services. The baseline measure was carried out in 2004 and 93 critical points, associated with different indicators, were identified. In 2010 critical points were reduced to 33 to ensure comparability and a second 
measurement was taken between 2012 and 2015. The methodology evaluates the civil service models in eight subsystems: (i) human resources planning; (ii) work organisation; (iii) employment management; (iv) performance management; (v) compensation management; (vi) development management; (vii) human and social relations management; and (viii) human resources function organisation. This permits the calculation of five aggregate indexes: efficiency, merit, structural consistency, functional capacity, and integrating capacity. The details of this methodology can be reviewed in Longo and Iacoviello (2010), Iacoviello and Strazza (2014), and OECD (2016).

The merit index serves precisely to evaluate the degree of politicisation of the civil service models, since their critical points are: (i) recruitment for the filling of posts open to all candidates that fulfil the required criteria based on technical requirements; (ii) the existence of mechanism and procedures to prevent arbitrariness in the selection; and (iii) dismissal of technical personal not motivated by political changes. The regional average in 2004 was 33 points on a scale of 100 , which rose to 45 in the 2012-2015 measurement. The countries with a weak merit-based recruitment process are Bolivia, Honduras, Guatemala, and Panama. The most dramatic fall in the last decade was in Bolivia. In contrast, countries with a high index are Brazil, Uruguay, and Costa Rica (Fig. 1).

The five indexes showed an increase from 2004. However, the most important advance is reflected precisely in the merit index, followed by structural consistency (Longo and Echebarría 2014). Furthermore, with the evaluation of the civil service models of 16 Latin American countries by IDB, it is also possible to calculate the Civil Service Development Index (CSDI) as an aggregate index for most countries in the region. The regional average of CSDI for 2012-2015 reaches 40 points on a scale of 100 , which implies a rise of 10 points in the past decade. Bolivia, Honduras, and Guatemala are the countries with the lowest indexes. The deterioration of the Bolivian civil service model is relevant and occurred specifically because, as from 2006, the government decided to prioritise direct appointments without tenders in order to favour historically marginalised sectors (Iacoviello and Strazza 2014). Nevertheless, there are cases that have improved substantially over the last decade, with Peru, Ecuador, and El Salvador standing out here, registering an increase of more 
than 20 points. El Salvador, for example, managed this important increase thanks to the creation of a unit of coordination and gradual implementation of tenders, whereas in Ecuador the drive was associated chiefly with the creation of the Public Service Vice-Ministry (Viceministerio del Servicio Público) (Iacoviello and Strazza 2014). The countries with the highest indexes are Chile, Brazil, and Costa Rica (Fig. 2). Brazil and Chile particularly are the most consolidated countries in the region. Whereas Chile shows greater development due to expansion and consolidation of its System of High-Level Public Management (Sistema de Alta Dirección Pública) (GonzálezBustamante et al. 2016), Brazil displays less dynamism despite the fact that in the past decade it consolidated a general performance evaluation system (Iacoviello and Strazza 2014).

In summary, the professionalisation of the Latin American civil service models presents range of nuances. One important group of countries, as Iacoviello and Strazza (2014) point out, has achieved several improvements after setting out from a low baseline in 2004. Another group of countries, which set out from a medium to medium-high baseline, shows relative stagnation. Finally, only Chile shows significant advances in different dimensions, having departed from a high baseline. Furthermore, certain gaps can be perceived between merit and the CSDI. The most relevant negative gap is presented by Bolivia, which has a very low level of merit in comparison with the development of its civil service model, which suggests that there are other indexes that elevate its development, e.g. efficiency, structural consistency, functional capacity, and integrating capacity. Then there is the Brazilian case, which works in the opposite way. The merit in its model is very elevated for its level of development, which is, at any rate, one of the most consolidated in the region. There are cases where a balance is observed, such as Chile, Mexico, and El Salvador.

In general, the advances and setbacks in the development of the civil service models in Latin America are tied to the dynamics in the processes of reform and the national agendas for modernisation. According to Cortázar et al. (2014b), in the last decade, it is possible to identify three types of reforms associated with the civil service which have different kinds of results in the region: (i) the professionalisation of management level, e.g. Chile, Peru, and Uruguay; (ii) the development of guarantees against politicisation, e.g. Paraguay and the Dominican Republic; and 
(iii) compensation management, e.g. Costa Rica, Honduras, and Paraguay.

\section{CONCLUSION}

The civil service models are systems of management of public employment and recruitment of civil servants. In recruitment, there is a tension between merit and political confidence. The opposition between merit-based recruitment and the political appointees is associated with the classical politics-administration dichotomy. This concept implies separating the political and the administrative spheres in government. Defenders of merit and professionalisation point out that these prevent the political use of the public administration. However, extreme professionalisation can generate a bureaucratic autonomy which puts democratic representativeness at risk. A civil service model can be classified according to different elements, one of the most relevant of these being its degrees of openness and tension between politicisation and professionalisation.

In Latin America, the patronage systems and clientelism of the nineteenth and twentieth centuries limited the evolution of civil service models. Subsequently, in the second half of the twentieth century, the New Public Management and the neoconservative reforms conditioned the modernisation of the public sector and of the civil service models. At the end of the twentieth century, the second-generation reforms of the World Bank boosted a reinvention of the public sector in order to generate capacities for regulation and the fight against corruption. In this context, the idea of having a body of senior civil servants separated from the political and bureaucratic spheres became relevant. Also, the need to rely on professional civil services grew.

That growing need in Latin America was crystallised with the Ibero-American Charter for Public Service in 2003. Following the fundamentals of this charter, the IDB designed a methodology which allowed to evaluate the models via different subsystems and to obtain an aggregate index of development with which changes over time can be analysed. Thanks to this, we can observe that the professionalisation of the Latin American civil services has different nuances. There is a first group of countries which in the past decade had civil service models with a low level of development and achieved partial improvements. In this group, some isolated cases attained significant improvements. Then, there is a second group of countries whose models had a medium- 
high development and presented a relative stagnation in recent years. Finally, only Chile and Brazil have a highly developed model, and in the past ten years only Chile has shown significant advances.

\section{References}

Ballart, X. and Ramió, C. (2000). Ciencia de la administración. Tirant lo Blanch, Valencia.

Barzelay, M. (2001). The New Public Management: Improving Research and Policy Dialogue. University of California Press, Berkeley.

Barzelay, M. (2003). "Introduction the Process Dynamics of Public Management Policymaking." International Public Management Journal, 6(3), 251-282.

Christensen, T. and Lægreid, P. (2011). "Introduction.” The Ashgate Research Companion to New Public Management, T. Christensen and P. Lægreid, eds., Ashgate, Farnham.

Cortázar, J. C., Lafuente, M., and Sanginés, M. (2014a). "Strengthening the Civil Service as a Pillar of Public Sector Institutions." Serving Citizens: A Decade of Civil Service Reforms in Latin America (2004-13), J. C. Cortázar, M. Lafuente, and M. Sanginés, eds., IDB, Washington D. C.

Cortázar, J. C., Lafuente, M., and Schuster, C. (2014b). "Strategies to Modernize the Civil Service in Latin America." Serving Citizens: A Decade of Civil Service Reforms in Latin America (2004-13), J. C. Cortázar, M. Lafuente, and M. Sanginés, eds., IDB, Washington D. C.

Echeberría, K. (2006). Informe sobre la situación del servicio civil en América Latina. IDB, Washington D. C.

Evans, P. and Rauch, J. E. (1999). "Bureaucracy and Growth: A Cross-National Analysis of the Effects of "Weberian" State Structures on Economic Growth." American Sociological Review, 64(5), 748-765.

Farazmand, A. (1989). State, Bureaucracy, and Revolution: Agrarian Reform of System Maintenance? Praeger, New York.

Farazmand, A. (1997). "Introduction.” Modern Systems of Governement: Exploring the Role of Bureaucrats and Politicians, A. Farazmand, ed., SAGE Publications, Inc., California. 
Frederickson, H. G., Smith, K. B., Larimer, C. W., and Licari, M. J. (2012). The Public Administration Theory Primer. Westview Press, Boulder.

González-Bustamante, B., Olivares, A., Abarca, P., and Molina, E. (2016). "Servicio civil en Chile, análisis de los directivos de primer nivel jerárquico (2003-13)." Revista de Administração Pública, 50(1), 59-79.

Grindle, M. S. (2012). Jobs for the Boys: Patronage and the State in Comparative Perspective. Harvard University Press, Cambridge.

Henderson, J., Hulme, D., Jalilian, H., and Phillips, R. (2007). "Bureaucratic Effects: "Weberian" State Agencies and Poverty Reduction.” Sociology, 41(3), 515-532.

Hood, C. (1991). “A Public Management for All Seasons?.” Public Administration, 69(1), 3-19. Iacoviello, M. and Strazza, M. (2014). "Diagnostic of the Civil Service in Latin America.” Serving Citizens: A Decade of Civil Service Reforms in Latin America (2004-13), J. C. Cortázar, M. Lafuente, and M. Sanginés, eds., IDB, Washington D. C.

Kaufman, H. (1956). "Emerging Conflicts in the Doctrines of Public Administration.” American Political Science Review, 50(4), 1057-1073.

Lafuente, M., Schuster, C., and Rojas-Wettig, M. (2013). "Dinámicas, condicionantes políticas y enfoques viables de reformas del servicio civil: lecciones de América Latina." Paper presented at the XVIII Congreso Internacional del CLAD sobre Reforma del Estado y de la Administración Pública, Montevideo.

Lewis, D. E. (2008). The Politics of Presidential Appointments. Princeton University Press, Princeton.

Llano, M. M. (2015). "Revisando la presunta naturaleza paradigmática de la Nueva Gerencia Pública y su repercusión en Iberoamérica.” Documentos y Aportes en Administración Pública y Gestión Estatal, 15(24), 67-99.

Longo, F. (2001). La reforma del servicio civil en las democracias avanzadas: mérito con flexibilidad. IDB, Washington D. C.

Longo, F. (2003). "La reforma del empleo público en las democracias avanzadas: mérito con 
flexibilidad." Servicio civil: temas para un diálogo, K. Echebarría, ed., IDB, Washington D. C. Longo, F. and Echebarría, K. (2014). "Behind the Results: A Snapshot of the Progress Made and Opportunities for Enhancing the Civil Service in Latin America." Serving Citizens: A Decade of Civil Service Reforms in Latin America (2004-13), J. C. Cortázar, M. Lafuente, and M. Sanginés, eds., IDB, Washington D. C.

Longo, F. and Iacoviello, M. (2010). "Evaluación del grado de implementación de la Carta Iberoamericana de la Función Pública en los países de América Latina.” Paper presented at the Conferencia Interregional de Ministros/Jefes de Administración Pública, CLAD, Buenos Aires.

Martínez Puón, R. (2012). "Hacia la profesionalización de la función directiva en Latinoamérica." Revista de Gestión Pública, I(2), 387-419.

Nef, J. (2003). "Public Administration and Public Sector Reform in Latin America." Handbook of Public Administration, G. Peters and J. Pierre, eds., SAGE Publications, Inc., London.

OECD (2008). The Senior Civil Service in National Governments of OECD Countries. OECD, Paris.

OECD (2016). Panorama de las Administraciones Públicas: América Latina y el Caribe 2017. OECD, Paris.

Olavarría-Gambi, M. and Dockendorff, A. (2016). "Implementing Meritocracy in Senior Public Administration: the Dilemma for Chilean Politicians.” Public Organization Review, 16(4), 561582.

Olsen, J. P. (2006). "Maybe It Is Time to Rediscover Bureaucracy." Journal of Public Administration Research and Theory, 16(1), 1-24.

Oszlak, O. (2001). El Servicio Civil en América Latina y el Caribe: situación y retos futuros Diálogo Regional de Política. IDB, Washington D. C.

Peters, B. G. (1995). The Politics of Bureaucracy. Longman, New York.

Peters, B. G. and Pierre, J. (2004). "Politicization of the Civil Service: Concepts, Causes, Consequences." Politicization of the Civil Service in Comparative Perspective: The Quest for Control, 
B. G. Peters and J. Pierre, eds., Routledge, New York.

Pollitt, C. and Bouckaert, G. (2002). Public Management Reform. A Comparative Analysis. Oxford University Press, New York.

Quermonne, J.-L. (1995). La organización administrativa del Estado. Escola d'Administració Pública de Catalunya, Barcelona.

Raadschelders, J. C. N. and Rutgers, M. R. (1996). "The Evolution of Civil Service Systems.” Civil Service Systems in Comparative Perspective, H. A. G. M. Bekke, J. L. Perry, and T. A. J. Toonen, eds., Indiana University Press, Bloomington.

Ramió, C. and Salvador, M. (2005). "Servicio civil en América Latina: reflexiones y propuestas tentativas." Documentos y Aportes en Administración Pública y Gestión Estatal, 5(6), 63-90.

Ramos, C. and Scrollini, F. (2013). "Los nuevos acuerdos entre políticos y servidores públicos en la alta dirección pública en Chile y Uruguay." Revista Uruguaya de Ciencia Política, 22(1), 11-36.

Resh, W. G. (2015). Rethinking the Administrative Presidency. Johns Hopkins University Press, Baltimore.

Rockman, B. A. (1996). "Conclusion.” Agenda for Excellence: Administering the State, B. G. Peters and B. A. Rockman, eds., Chatham House, Chatham.

Santiso, C. (2001). “Gobernabilidad democrática y reformas económicas de segunda generación en América Latina.” Revista Institutciones y Desarrollo, (8-9), 325-366.

Wilson, W. (1887). “The Study of Administration.” Political Science Quarterly, 2(2), 197-222. 


\section{List of Figures}

1 Civil Service Models in Latin America, own elaboration with IDB data updated to June 2017 , scale from 0 to $100 \ldots \ldots \ldots$

2 Civil Service Models in Latin America, own elaboration with IDB data updated to June 2017 , scale from 0 to $100 \ldots \ldots \ldots \ldots$ 


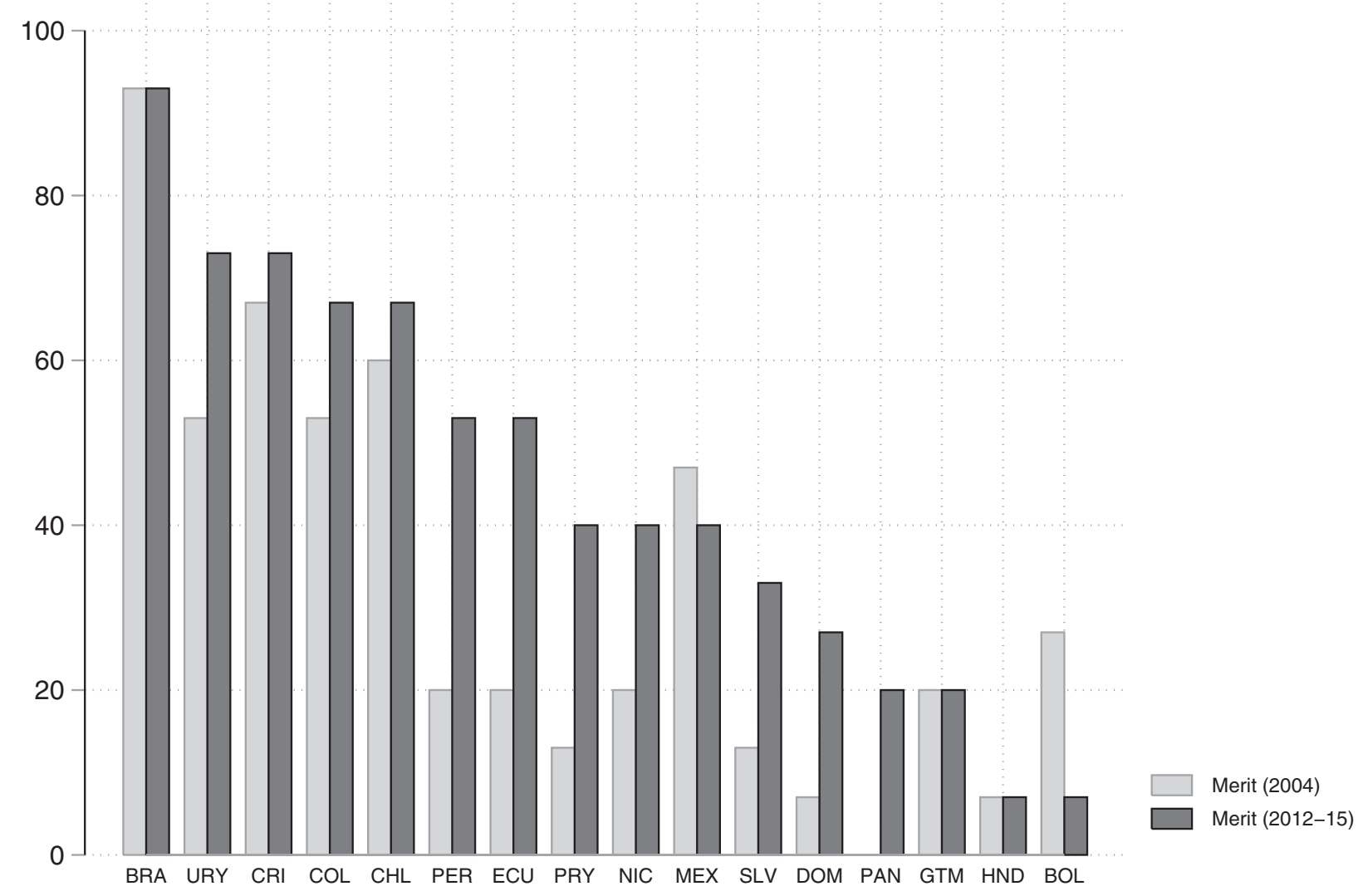

Figure 1. Civil Service Models in Latin America, own elaboration with IDB data updated to June 2017, scale from 0 to 100 


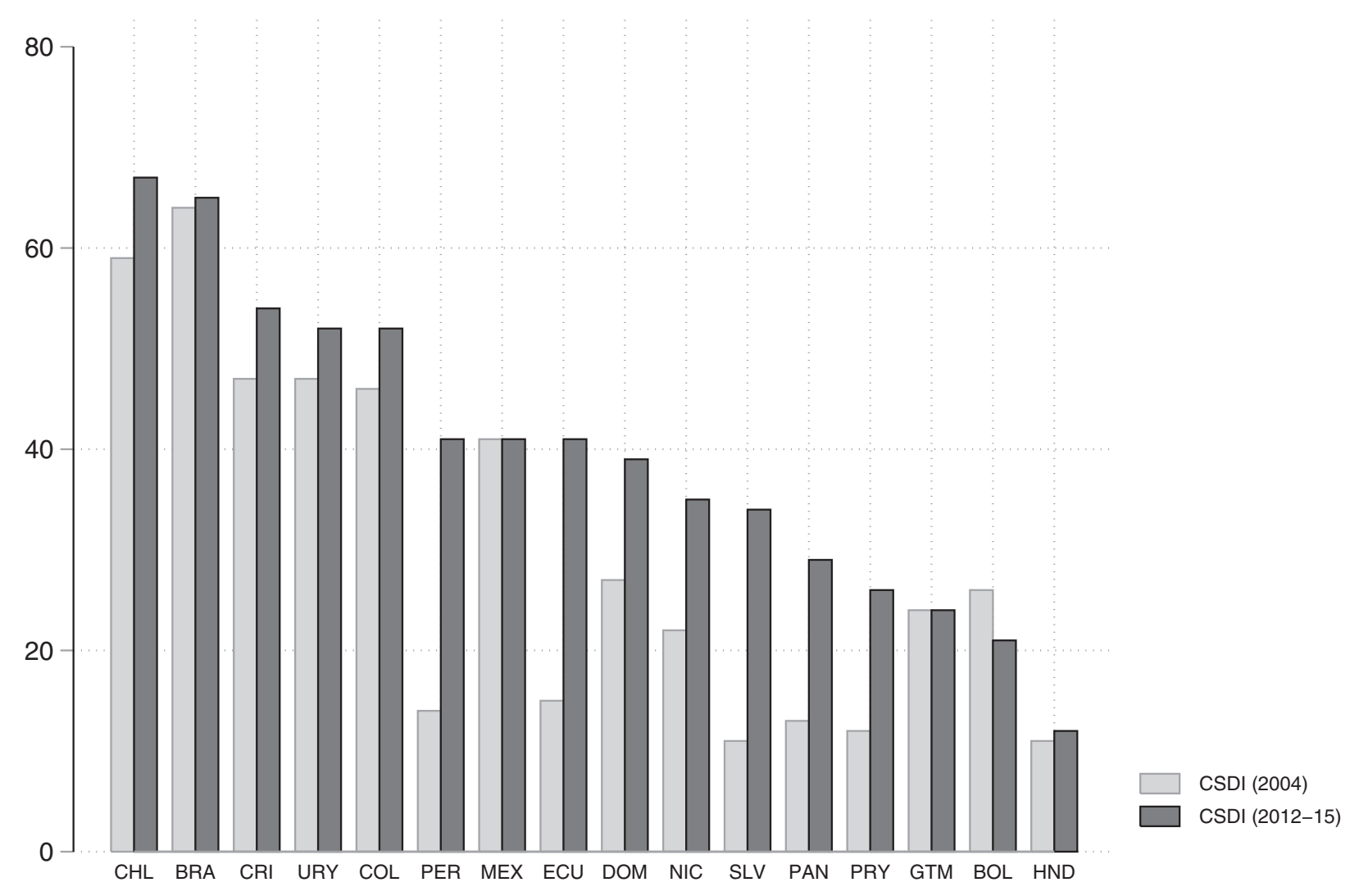

Figure 2. Civil Service Models in Latin America, own elaboration with IDB data updated to June 2017, scale from 0 to 100 